\title{
The association between circulating 25-hydroxyvitamin D concentration and Grip Strength and Timed-Up and Go test in 70+ year old adults: Baseline findings from the Vitamin D Supplementation in Older People (VDOP) study
}

\author{
R.M.T.K. Ranathunga ${ }^{1}$, T.R. Hill ${ }^{1}$, J.C. Mathers ${ }^{1}$, I. Schoenmakers ${ }^{2}$ and T.A. Aspray ${ }^{3}$ \\ ${ }^{1}$ Institute of Cellular Medicine, Human Nutrition Research Center, Newcastle University, Newcastle-upon-Tyne, \\ NE2 4HH, UK, ${ }^{2}$ MRC Human Nutrition Research, Cambridge, Medical School, University of East Anglia, Norwich, \\ NR4 7TJ, UK and ${ }^{3}$ Institute of Cellular Medicine, Freeman Hospital, Newcastle-upon-Tyne, NE7 7DN, UK.
}

Vitamin D has important regulatory effects in muscle tissue ${ }^{(1)}$. Cross sectional studies demonstrate that circulating 25 -hydroxyvitamin $\mathrm{D}$ (25OHD) [the indicator of vitamin D status] is associated with better muscle function but the optimal 25OHD concentration for muscle function is not universally agreed. The objective of this study was to identify the association between serum 25OHD concentration and Grip Strength (GS) and Timed-Up and Go test (TUG) using 25OHD thresholds used in North America $(\geqslant 50 \mathrm{nmol} /)^{(2)}$ and the UK $(\geqslant 25 \mathrm{nmol} / \mathrm{L})^{(3)}$ used to define nutritional adequacy for vitamin $\mathrm{D}$.

A total of 377 male and female adults aged $>70$ years living in the North-East of England were recruited. GS (in $\mathrm{kg}$ ) was measured by a hand grip dynamometer and TUG was measured as the time (in seconds (s)) to walk $2 \mathrm{~m}$ distance. Serum $25 \mathrm{OHD}$ concentration was measured by LC-MS. Weight, height and body composition were also measured. In separate analyses, individuals were grouped according to the circulating $25 \mathrm{OHD}$ concentration $<$ or $\geqslant 25 \mathrm{nmol} / \mathrm{L}$ and $<$ or $\geqslant 50 \mathrm{nmol} / \mathrm{L}$. Male and female older adults were grouped into two separately, based on the gender specific median values of GS and TUG test values. The odds ratios to have high GS and low TUG test values were identified using logistic regression analysis after adjusting for age, weight, height and body composition.

\begin{tabular}{|c|c|c|c|c|c|c|c|c|}
\hline \multirow{2}{*}{\multicolumn{2}{|c|}{ Classification }} & \multirow[b]{2}{*}{$\mathrm{n}$} & \multicolumn{3}{|c|}{ Males } & \multicolumn{3}{|c|}{ Females } \\
\hline & & & OR* & $\mathrm{CI}$ & $\mathrm{p}$ & OR* & CI & $\bar{p}$ \\
\hline \multirow{3}{*}{ SACN } & GS & & & & & & & \\
\hline & $25 \mathrm{OHD}<25 \mathrm{nmol} / \mathrm{L}$ & 102 & 0.371 & $0 \cdot 163-0 \cdot 841$ & 0.018 & 0.652 & $0.334-1.272$ & 0.209 \\
\hline & $25 \mathrm{OHD} \geqslant 25 \mathrm{nmol} / \mathrm{L}$ & 275 & Reference & & & Reference & & \\
\hline \multirow{2}{*}{ IOM } & $25 \mathrm{OHD}<50 \mathrm{nmol} / \mathrm{L}$ & 271 & 1.202 & $0.61-2.341$ & 0.588 & 0.739 & $0.355-1.538$ & 0.419 \\
\hline & $\begin{array}{l}25 \mathrm{OHD} \geqslant 50 \mathrm{nmol} / \mathrm{L} \\
\text { TUG test }\end{array}$ & 106 & Reference & & & Reference & & \\
\hline \multirow[t]{2}{*}{ SACN } & $25 \mathrm{OHD}<25 \mathrm{nmol} / \mathrm{L}$ & 102 & 1.274 & $0.59-2.741$ & 0.536 & 0.695 & $0.358-1.350$ & $0 \cdot 283$ \\
\hline & $25 \mathrm{OHD} \geqslant 25 \mathrm{nmol} / \mathrm{L}$ & 275 & Reference & & & Reference & & \\
\hline \multirow[t]{2}{*}{ IOM } & $25 \mathrm{OHD}<50 \mathrm{nmol} / \mathrm{L}$ & 271 & 0.910 & $0.474-1.74$ & 0.777 & 0.537 & $0.257-1 \cdot 120$ & 0.098 \\
\hline & $25 \mathrm{OHD} \geqslant 50 \mathrm{nmol} / \mathrm{L}$ & 106 & Reference & & & Reference & & \\
\hline
\end{tabular}

Mean serum 25OHD concentration of older adults was $39.8( \pm 19.9) \mathrm{nmol} / \mathrm{L}$. About $21.0 \%$ of males and $33.7 \%$ of females had serum 25OHD concentration less than $25 \mathrm{nmol} / \mathrm{L}$. Similarly, $67.9 \%$ of males and $76.2 \%$ of females had serum $25 \mathrm{OHD}$ concentration less than $50 \mathrm{nmol} / \mathrm{L}$. Only for male, those with serum $25 \mathrm{OHD}$ concentration lower than $25 \mathrm{nmol} / \mathrm{L}$ were significantly more likely to have lower GS compared to the individuals who had serum 25OHD concentration higher than 25 nmol/L. However, there was no significant relationship between 25OHD status and TUG for either gender. In conclusion, in male older adults, serum 25OHD concentration lower than $25 \mathrm{nmol} / \mathrm{L}$ is associated with lower GS but there was no evidence of musculoskeletal benefit from having serum $25 \mathrm{OHD}$ concentrations higher than $50 \mathrm{nmol} / \mathrm{L}$ for either gender. Therefore, based on this cross sectional analysis, the optimum serum $25 \mathrm{OHD}$ concentration to maximize the muscle strength for older males is likely to be between $25-50 \mathrm{nmol} / \mathrm{L}$.

The VDOP study is supported by a grant (MP/ID19544) from Arthritis Research UK and partly supported by Newcastle University and funding from the core programme of the MRC Nutrition and Bone Health Group at MRC Human Nutrition Research funded by the UK MRC, grant code U10596037.

1. Ceglia L (2009) Curr. Opin. Clin. Nutr 12, 628-633.

2. IOM (2011) Dietary reference intakes for calcium and vitamin D.

3. Scientific Advisory Committee in Nutrition (2016) Vitamin D and Health Report. 